\title{
EFFECT OFCO-ADMINISTRATION OF EMBLICA OFFICINALIS AND AEGLE MARMELOS EXTRACTS FOR ANTIOXIDANT AND ANTIDIABETIC ACTIVITY
}

\author{
HEMANT K. JAIN*, SNEHAL R. JAISWAL
}

Department of Quality Assurance Techniques, Sinhgad College of Pharmacy, Vadgaon (Bk.), Pune 411041, Maharashtra, India

Email: hemantkjain2001@yahoo.co.in

Received: 23 Nov 2018 Revised and Accepted: 17 May 2019

\begin{abstract}
Objective: The objective of the present study was to develop an HPLC analytical method and to perform in vivo study of Emblica officinalis and Aegle marmelos extracts for antioxidant and antidiabetic activity.

Methods: The phytochemical analyses, total phenolic content (TPC), TLC, DPPH assay were performed for freeze-dried Emblica officinalis fruits aqueous extract (EOFAE) and Aegle marmelos leaves ethyl acetate extract (AMLEAE). The active constituents present in both extracts were estimated by using HPLC system having Hibar ${ }^{\circledR}$ C18 column $[250 \times 4.6 \mathrm{~mm}, 5 \mu \mathrm{m}]$ and UV detector $(264 \mathrm{~nm})$. A gradient mobile phase (acetonitrile and water with $0.1 \%$ trifluoroacetic acid) was used at a flow rate of $0.8 \mathrm{ml} / \mathrm{min}$. In vivo antioxidant, antidiabetic activity of both extracts was conducted on male albino Wistar rats for $21 \mathrm{~d}$ in streptozotocin-induced diabetic rats (42 rats; $\mathrm{n}=6$ ). The antidiabetic activity was measured by blood glucose level and biochemical parameters i.e. total cholesterol, triglycerides and total protein. Oxidative stress was measured by antioxidant biomarkers i.e. SOD, GSH, lipid peroxidation by thiobarbituric acid reactive substances method on the liver of the experimental rat.
\end{abstract}

Results: Tannins, saponins, carbohydrate, glycosides are found in EOFAE; coumarins and flavonoids are found in AMLEAE and quinones, phenols are present in both extracts. The values of TPC present in standard gallic acid, EOFAE and AMLEAE were found to be 485.7, 315.6, 300.7 mgGAE/g respectively. $\mathrm{R}_{\mathrm{f}}$ values obtained by TLC of EOFAE and AMLEAE were found to be 0.41 and 0.50 , respectively. The values of \% inhibition shown by EOFAE and AMLEAE in DPPH assay were found to be $97.8 \% \pm 2$ and $95.2 \% \pm 2$, respectively. The values of retention time of EOFAE and AMLEAE by HPLC analysis were found to be 4.59 and $5.28 \mathrm{~min}$, respectively. Histopathological examination of the liver was revealed that low dose EOAM (containing of EOFAE 250+AMLEAE $250 \mathrm{mg} / \mathrm{kg}$ body weight) administered once a daily for $21 \mathrm{~d}$ showed significant activity (R0.001) with biochemical parameters and antioxidant biomarkers.

Conclusion: The present study showed that the EOFAE and AMLEAE treated group III with (EOAM) low dose of $500 \mathrm{mg} / \mathrm{kg}$ body weight has potent antioxidant and antidiabetic activity.

Keywords: Emblica officinalis, Aegle marmelos, Antioxidant, Antidiabetic activity, streptozotocin, HPLC

(C) 2019 The Authors. Published by Innovare Academic Sciences Pvt Ltd. This is an open-access article under the CC BY license (http://creativecommons.org/licenses/by/4.0/) DOI: http://dx.doi.org/10.22159/ijpps.2019v11i7.30948

\section{INTRODUCTION}

World Health Organisation (WHO) states that an estimated 1.6 million deaths were directly caused by diabetes in 2015 and projects that this disorder will be $7^{\text {th }}$ leading cause of death in 2030 [1]. Indian Council of Medical Research (ICMR) and the American Diabetes Association are working accordingly for the prevention and treatment of this disorder [2-4]. Diabetes mellitus is a chronic metabolic disorder caused by inherited and/or acquired deficiency in production insulin by the pancreas or by the ineffectiveness of the insulin produced. Such a deficiency results in increased concentrations of glucose in the blood, which in turn damage many of the body's systems, in particular, the blood vessels and nerves [5]. It affects all the vital organs such as heart, nerves, eyes, kidney, foot and associated with the chronic complications likes nephropathy, neuropathy, retinopathy and cardiovascular diseases. The most common types of diabetes are type 1-diabetes (insulin-dependent) in which the pancreas fails to produce the insulin which is essential for survival. This form develops most frequently in children, adolescents and they need to take insulin every day to stay alive. Type 2-diabetes (non-insulin dependent) occur due to reduce insulin secretion and insulin sensitivity. It mostly occurs in middle-aged and old-aged people. Gestational diabetes occurs in some pregnant women [6]. Oral hypoglycaemic agents like sulfonylureas, biguanides and thiazolidinediones are used in the treatment of type 2 diabetes. These drugs are required throughout life in most of the cases. Various side effects of these drugs are stomach upset, skin rash, kidney complications, dizziness, metal taste, gas, bloating and diarrhea, risk of liver disease. In the case of diabetes mellitus blood, glucose level and oxidative stress are high which increase the number of free radicals present in the body. Free radicals are highly reactive in other words increasing in oxidative stress [7]. The constituents of medicinal plants activate free radical scavenging enzymes and have antioxidant activity as well as antidiabetic activity [8]. Various parts of medicinal plants like leaves, roots, bark and fruit are used by Ayurvedic practitioners for different therapeutic effects as they are safe, economical, least adverse effects [9]. Literature reports that water-soluble [10] extract of Emblica officinalis has potent antioxidant activity and hypoglycemic activity [11]. Emblica officinalis Gaertn. is also known as "Amla" traditionally, belonging to the family Euphorbiaceae [12]. It is one of the most important plants of Ayurveda and traditional Indian medicine [11]. Other reports indicate that marmelosin present in Aegle marmelos has antidiabetic activity [13-16]. Marmelosin (Imperatorin) is freely soluble in ethyl acetate extract [14]. Aegle marmelos traditionally also known as bael (golden apple) in India, which is belonging to family Rutaceae and one of the most important plant in the Ayurveda [15]. Components present in the leaf of Aegle marmelos have the ability to inhibit aldose reductase and help in delaying the progression of diabetic cataract [14]. Proposed project involves the co-administration of aqueous extract of Emblica officinalis fruits and ethyl acetate extract of Aegle marmelos leaves for antioxidant and antidiabetic activity.

\section{MATERIALS AND METHODS}

Shade-dried fruits of Emblica officinalis and leaves of Aegle marmelos were purchased from Green Pharmacy, Pune (Auth. 18-13, Auth. 1814) Maharashtra, India. Both drugs were authenticated from Agharkar Research Institute, Pune, India. HPLC grade of Acetronitrile, AR grade of Ascorbic acid, gallic acid were purchased from Loba-chemie, Mumbai, India. Streptozotocin was purchased 
from Enzo Life Science, UK. Diagnostic kits were procured from Biolab, Span and Tulip diagnostic Pvt. Ltd., Boisar, Maharashtra, India. Glibenclamide was purchased from Torrent Pharmaceuticals, Ltd, Bhat, Gandhinagar, Gujarat, India. Male Albino Wistar rats were obtained from Global Bioresearch Solution Pvt. Ltd., Pune, India.

\section{Instruments}

The analytical method was performed on Shimadzu HPLC (LC 2010 CHT, Japan) having a quaternary system with automatic injection facility, LC solution software and UV visible detector. The column used was Purospher Star RP-18e, Hibar C-18 (250 mm x 4.6 mm, 5 $\mu \mathrm{m})$. Shimadzu (UV-1800) UV-visible spectrometer, Bruker (Alpha-T model) FT-IR, Martin Christ (Alpha 1-2 LD plus) Freeze dryer, Equiptronics (EQ-610) digital pH meter and Shimadzu (AYT 224) analytical balance were employed for this study.

\section{Preparation of extracts}

\section{Preparation of Emblica officinalis fruits extract}

Shade-dried powder of the Emblica officinalis fruits (50 gm) was macerated with $500 \mathrm{ml}$ of water for $24 \mathrm{~h}$ at $25-30^{\circ} \mathrm{C}$ with occasional shaking and filtered through a muslin cloth and then filtered through Whatman filter paper $(0.45 \mu)$. Filtrate was freeze-dried under vaccum at $-50^{\circ} \mathrm{C} \pm 2^{\circ} \mathrm{C}$ to get dry powder. Freeze-dried extract were stored at below $4{ }^{\circ} \mathrm{C}$ until further use $[10,12]$.

\section{Preparation of Aegle marmelos leaves extract}

Shade-dried powder of Aegle marmelos leaves (150 gm) was macerated with $300 \mathrm{ml}$ of ethyl acetate for $72 \mathrm{~h}$ at $25-30{ }^{\circ} \mathrm{C}$ in a suitable container. The solvent evaporation was protected by wrapping of the container with aluminium foil. The menstruum was filtered through muslin cloth and then filtered through Whatman filter paper $(0.45 \mu)$. Filtrate was concentrated by using a vaccum rotary evaporator and kept it at $37^{\circ} \mathrm{C}$ to remove any traces of solvent. This concentrated extract was freeze-dried under vaccum at $-50{ }^{\circ} \mathrm{C} \pm 2{ }^{\circ} \mathrm{C}$ to get the dry powder and stored at below $4{ }^{\circ} \mathrm{C}$ until further use [14].

\section{Phyto-chemical investigation}

Both the extracts were evaluated for preliminary phytochemical investigation and alkaloids, tannins, proteins, saponins, quinones, coumarins, phenols, flavonoids, carbohydrates, glycosides and sterols tests were performed [12].

\section{Total phenolic content}

Total phenolic content of EOFAE and AMLEAE was determined by the Folin-Ciocalteu method. Each extract ( $150 \mu \mathrm{l})$ was mixed with $0.5 \mathrm{ml}$ of Folin-Ciocalteu phenol reagent and stand for $5 \mathrm{~min}$ and then $350 \mu \mathrm{l}$ of $10 \% \mathrm{Na} 2 \mathrm{CO} 3$ was added. Each reaction mixture was incubated for $2 \mathrm{~h}$ period at room temperature and absorbance was measured at $765 \mathrm{~nm}$ by using double beam UV visible spectrophotometer. The standard gallic acid solution in methanol was prepared in the range of concentrations $0.2,0.4,0.6,0.8$ and $1 \mathrm{mg} / \mathrm{ml}[12,17]$.

\section{Thin layer chromatography (TLC)}

Acetonitrile: $0.1 \%$ trifluoroacetic acid in water in the ratio 2.5: 7.5 $\mathrm{v} / \mathrm{v}$ was used as a mobile phase for TLC of EOFAE.

Toluene: ethyl acetate: glacial acetic acid: methanol in the ratio 8: 2: $0.2: 0.2 \mathrm{v} / \mathrm{v}$ was used as a mobile phase for TLC of AMLEAE [18].

\section{In vitro antioxidant assay}

\section{DPPH (1,1-diphenyl-2-picrylhydrazyl) free radical scavenging activity}

DPPH radical scavenging method developed by Blois was used [12, 19-21]. Antioxidant activity of the each extract was compared with the natural antioxidant ascorbic acid. Stock solution of DPPH was prepared by dissolving $24 \mathrm{mg}$ of DPPH in $100 \mathrm{ml}$ of methanol and stored at $-20^{\circ} \mathrm{C}$. Working standard solution was prepared by $10 \mathrm{ml}$ of the stock solution to $45 \mathrm{ml}$ of methanol and absorbance was recorded at $515 \mathrm{~nm}$. Extracts of both drugs $(100 \mu \mathrm{g} / \mathrm{ml})$ were added to $2.85 \mu \mathrm{l}$ of DPPH working standard and kept in dark for $30 \mathrm{~min}$. The absorbances of both solutions were measured at $515 \mathrm{~nm}$.
Control was prepared in the same manner without the addition of the extract. Percent inhibition of DPPH free radical was calculated by the following formula:

$$
\text { Inhibition }(\%)=\left[\left(A_{\text {control }}-A_{\text {test }}\right) / A_{\text {control }}\right] \times 100
$$

Where $A_{\text {control }}$ is the absorbance of DPPH radical solution in methanol. $A_{\text {test }}$ is the absorbance of DPPH radical solution mixed with each extract.

\section{HPLC method development}

Detection wavelengths for HPLC analysis were selected by scanning $100 \mu \mathrm{g} / \mathrm{ml}$ solution of each extract separately by double beam UVvisible spectrophotometer in the range of 200-400 nm. Stationary phase ODS in Hibar ${ }^{\circledR}$ C18 column [ $\left.250 \times 4.6 \mathrm{~mm}, 5 \mu \mathrm{m}\right]$ was used in HPLC. Standard solutions of both extracts were prepared separately for HPLC analysis [22].

\section{Preparation of the mobile phase}

Solvents (HPLC grade) of mobile phase (Acetonitrile and $0.1 \% \mathrm{v} / \mathrm{v}$ of TFA in water) were filtered through $0.45 \mu$ membrane filter paper separately and sonicated to degas. These solvents were transferred in two different reservoirs of the HPLC system.

\section{Preparation of standard solutions}

$100 \mathrm{mg}$ of EOFAE was accurately weighed and transferred into the 100 $\mathrm{ml}$ volumetric flask. It was then dissolved in water (HPLC grade) and volume was made up to the mark to prepare a standard stock solution. This solution was further diluted up to $100 \mu \mathrm{g} / \mathrm{ml}$ with water.

$100 \mathrm{mg}$ of AMLEAE was accurately weighed and transferred into the $100 \mathrm{ml}$ volumetric flasks. It was then dissolved in ethyl acetate and volume was made up to the mark to prepare a standard stock solution. This solution was further diluted up to $100 \mu \mathrm{g} / \mathrm{ml}$ with ethyl acetate.

\section{Preparation of sample solutions}

Water $(100 \mathrm{ml})$ was transferred to the separating funnel and accurately weighed the quantity of powder (equivalent to $200 \mathrm{mg}$ of each extract) was added to it. The mixture was shaken and $100 \mathrm{ml}$ of ethyl acetate was added to it. The resultant mixture was shaken for $10 \mathrm{~min}$ and kept for $6 \mathrm{~h}$ with occasional shaking. The layers were separated and collected carefully. These solutions were further diluted suitably in the range of standard solutions.

\section{Fourier transform infrared (FT-IR) spectral analysis}

FT-IR analysis of EOFAE [24] and AMLEAE [25] was done for the presence of the functional group in extracts. The dry sample of each extract was mixed with potassium bromide (IR grade) in the ratio 1:100. This mixture was compressed to form pellets by applying 10 tons of pressure in hydraulic press. The pellet was scanned over a wave number range of 4000 to $400 \mathrm{~cm}^{-1}$ by using FT-IR instrument.

\section{In vivo antidiabetic study}

\section{Experimental animals}

The experimental protocol [SCOP/IAEC/17-18/07/252, dated 23.02.2018] was approved by the Institutional Animal Ethics Committee (IAEC) of Sinhgad College of Pharmacy, Pune. Forty-two Male Albino Wistar rats of weight 180-240 g were used in this project. The animals were housed in large, spacious polypropylene cages with paddy husk as bedding at an ambient room temperature with $12 \mathrm{~h}$ light and dark cycle. The animals fed with standard pellet diet (Nutrivet Lab, Pune) and water ad libitum throughout the experimental duration.

\section{Induction of diabetes on experimental rats}

After adequate acclimatisation period, rats were randomly divided into normal control (group 1, $\mathrm{n}=6$ ) and diabetic model (group 2, $\mathrm{n}=36$ ). Freshly prepared streptozotocin (STZ) [in freshly prepared $0.1 \mathrm{~mol} / \mathrm{l}$ cold citrate buffer, $\mathrm{pH}$ 4.5] was administered intraperitoneally to an overnight fasted rat at a dose of $50 \mathrm{mg} / \mathrm{kg}$ body weight [8]. The STZ treated animals were allowed to drink $5 \%$ glucose solution overnight to overcome STZ-induced hypoglycaemia. 
After $48 \mathrm{~h}$, rats with marked hyperglycemia (fasting blood glucose $\geq 250 \mathrm{mg} / \mathrm{dl}$ ) were selected and used for the study.

\section{Experimental animal grouping and treatment}

Diabetic animals were treated with low dose combination [EOAM] and high dose combination daily through oral gavage for three weeks and co-administration of glibenclamide with low or high dose of EOAM, glibenclamide ( $5 \mathrm{mg} / \mathrm{kg}$ ). The suspension of EOAM was prepared with $2 \%$ of gum acacia. The diabetic animals were further divided into five groups consisting 6 animals each as follows, (1) group 3, low dose (containing of EOFAE 250+AMLEAE $250 \mathrm{mg} / \mathrm{kg} \mathrm{bw}$ ), (2) group 4, high dose (containing of EOFAE $500+$ AMLEAE $500 \mathrm{mg} / \mathrm{kg} \mathrm{bw}$ ), (3) group 5, low dose with glibenclamide (low dose of each extract+glibenclamide 5 $\mathrm{mg} / \mathrm{kg}$ body weight), (4) group 6 , high dose with glibenclamide (high dose of each extract+glibenclamide $5 \mathrm{mg} / \mathrm{kg}$ body weight) and(5) group 7, treated with glibenclamide $5 \mathrm{mg} / \mathrm{kg}$ body weight used as reference drug [11].

\section{Body weight}

Body weight was recorded at the end of three-week treatment by gravimetrically using the electronic digital balance.

\section{Biochemical analysis}

Rats were fasted overnight and the blood was withdrawn by retro-orbital puncture on 1st day and 21st day post-induction for the estimation of various biochemical parameters, i.e., total cholesterol, total triglyceride, total protein [28-31]. Blood sample was centrifuged for $20 \mathrm{~min}$ at $5000 \mathrm{rpm}$ at $37^{\circ} \mathrm{C}$ and serum was separated for the biochemical estimation. All the analysis was completed within $24 \mathrm{~h}$ from sample collection. Blood glucose level (BGL) was determined by commercial glucometer by pricking tail vein.

\section{Estimation of oxidative stress}

At the end of treatment, the animals were allowed for fasting 16 $h$ and they were sacrificed by sodium pentobarbital then the liver was carefully removed, weighed and washed with ice-cold saline. One gram of liver was homogenized with buffer containing $0.25 \mathrm{M}$ sucrose and $0.1 \mathrm{M}$ Tris-HCL buffer solution (pH 7.4). The homogenate was centrifuged at $10000 \mathrm{x} g$ for 10 min at $0{ }^{\circ} \mathrm{C}$ in cold centrifuge; separated supernatant was again centrifuged at $10000 \mathrm{x} \mathrm{g}$ for $30 \mathrm{~min}$ and then used for the antioxidant enzyme estimations [8]. Antioxidant enzymes were estimated by SOD, GSH and LPO. A level of superoxide dismutase (SOD) was estimated, reduced glutathione (GSH) was estimated by the method of Ellman (1959), and lipid peroxidation was estimated by thiobarbituric acid reactive substances (TBARS) method was done [8-9, 32-34].

\section{Histopathology}

At the end of the experiment, whole liver from each animal were collected in $10 \%$ formalin solution and an immediately processed using paraffin technique. Thin section $(5 \mu \mathrm{m})$ were cut and stained with hematoxylin and eosin. The tissue sample was examined and observed under a light microscope for structural abnormality.

\section{Statistical analysis}

All data sets were expressed as the mean $\pm \operatorname{SEM}(n=6)$. Data sets were subjected to One-way analysis of variance (ANOVA) followed by the Tukey's test. $\mathrm{p}<0.05$ was considered as a minimum level of significance. Statistical analysis was performed using the software GraphPad prism 5.01.

\section{RESULTS AND DISCUSSION}

Aqueous extract of Emblica officinalis fruit was selected because active constituents are water-soluble, i.e. ascorbic acid and tannins like emblicanin A and B which are antioxidant. Similarly, ethyl acetate extract of Aegle marmelos leaves was selected because active constituent marmelosin is soluble in it. The \% yield was obtained for the EOFAE and AMLEAE $30 \%$ and $5.33 \%$, respectively. Results of phytochemical investigation for EOFAE and AMLEAE are shown in table 1.

\section{Total phenolic content}

The total phenolic contents of gallic acid, EOFAE and AMLEAE were found to be 485.7, 315.6 and 300.7 milligrams of gallic acid equivalent per gram of dried extract (mgGAE/g), respectively. These results indicated that EOFAE and AMLEAE have sufficient phenolic content for antioxidant activity.

\section{Thin layer chromatography}

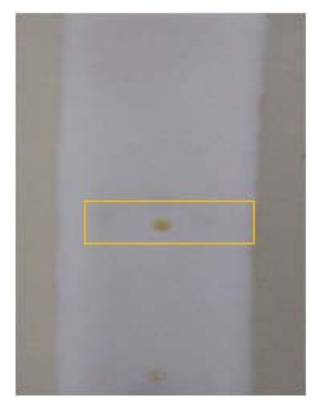

Fig. 1: TLC for EOFAE

TLC showed single dark brown colour spot in normal day light at $\mathrm{R}_{\mathrm{f}}$ value at 0.41 for ascorbic acid as shown in fig. 1 .

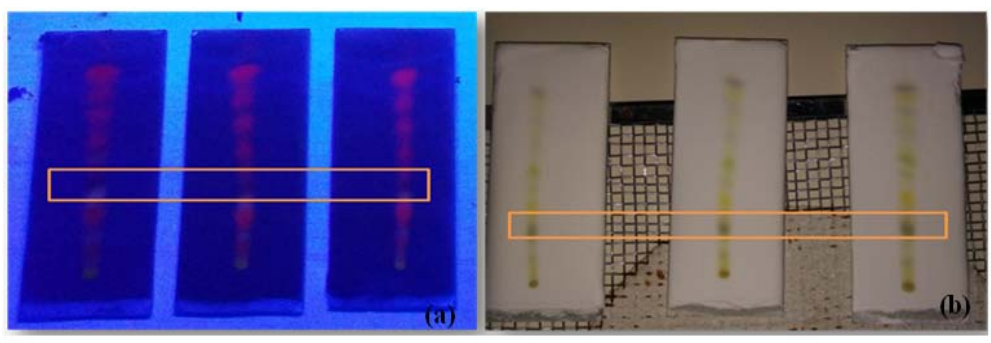

Fig. 2: TLC for AMLEAE (a) under UV light and (b) in normal day light

TLC showed a single dark violet colour spot was observed under UV light and in normal day light at $\mathrm{R}_{\mathrm{f}}$ value at 0.5 for marmelosin as shown in fig. 2.

\section{Antioxidant assay by in vitro}

DPPH (1, 1-diphenyl-2-picrylhydrazyl) free radical scavenging activity

DPPH is a stable free radical that reacts with compounds that can donate a hydrogen atom. The decline capability of DPPH radical is determined by the decrease in absorbance at $515 \mathrm{~nm}$ induced by antioxidants. The extracts are able to reduce the stable radical DPPH to the yellowcoloured diphenylpicryl hydrazine. The free radical scavenging activity was shown $97.08 \%$ by EOFAE and $95.06 \%$ by AMLEAE shown in fig. 3 .

\section{Optimization of chromatographic conditions}

The significant absorbance of both extracts was found at $264 \mathrm{~nm}$; therefore this wavelength was selected as the detection wavelength for analysis of both extract by HPLC. Initially, various 
chromatographic conditions were tried for both extracts separately, in order to obtain better separation characteristics by changing mobile phase composition. Finally, the mobile phase containing acetonitrile: water (0.1\% trifluoroacetic acid) 15:85 was selected for analysis of EOFAE and acetonitrile: water ( $0.1 \%$ trifluoroacetic acid)
13:87 was selected for analysis of AMLEAE. The flow rate of mobile phase for extracts was $0.8 \mathrm{ml} / \mathrm{min}$. The values of retention time for an active constituent of EOFAE and AMLEAE were found at 4.59 and $5.24 \mathrm{~min}$, respectively. Optimized chromatographic conditions are mentioned in table 2 and fig. 4 (a) and (b)

Table 1: Phyto-chemical investigation for EOFAE and AMLEAE

\begin{tabular}{|c|c|c|}
\hline Phyto-chemical test & Eofae & Amleae \\
\hline Tannins & $(+)$ & $(-)$ \\
\hline Saponins & $(+)$ & $(-)$ \\
\hline Quinones & $(+)$ & $(+)$ \\
\hline Coumarins & $(-)$ & $(+)$ \\
\hline Phenols & $(+)$ & $(+)$ \\
\hline Carbohydrate & $(+)$ & $(-)$ \\
\hline Glycosides & $(+)$ & $(-)$ \\
\hline Flavonoids & $(-)$ & $(+)$ \\
\hline
\end{tabular}

$(+)$ : Present, (-): Absent

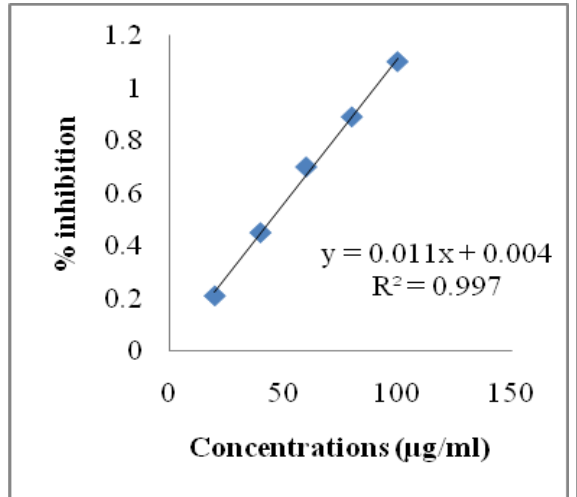

(a)

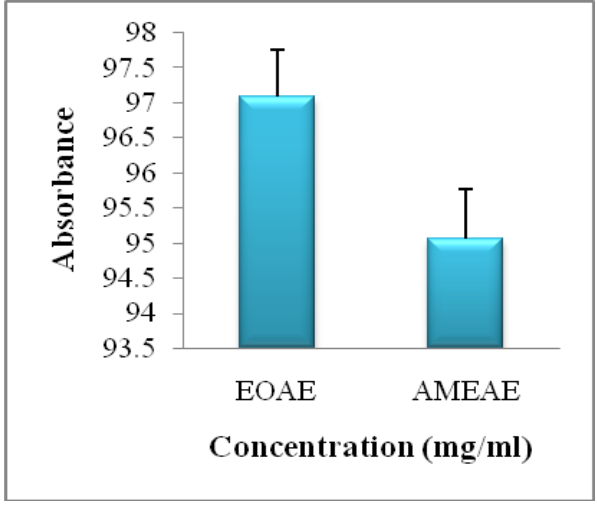

(b)

Fig. 3: (a) Ascorbic acid standard curve, (b) shows DPPH (1, 1-diphenyl-2-picrylhydrazyl) \% inhibition. Free radical scavenging activity for EOFAE and AMLEAE

Table 2: Optimized chromatographic conditions

\begin{tabular}{llll}
\hline S. No. & Parameters & Eofae & Amleae \\
\hline 1 & Mobile phase & Acetonitrile: water $(0.1 \% \mathrm{TFA})$ & \\
2 & Column & Purospher Star RP-18, Hibar C-18 $(250 \mathrm{~mm} \times 4.6 \mathrm{~mm}, 5 \mu \mathrm{mm})$ \\
3 & Ratio & $15: 85 \mathrm{v} / \mathrm{v}$ & $0.8 \mathrm{ml} / \mathrm{min}$ \\
4 & Flow rate & $0.8 \mathrm{ml} / \mathrm{min}$ & $30^{\circ} \mathrm{C}$ \\
5 & Column temperature & $30{ }^{\circ} \mathrm{C}$ & $264 \mathrm{~nm}$ \\
6 & Detection wavelength & $264 \mathrm{~nm}$ & $30 \mu \mathrm{l}$ \\
7 & Injection volume & $30 \mu \mathrm{l}$ & $20 \mathrm{~min}$ \\
8 & Run time & $20 \mathrm{~min}$ & $5.24 \mathrm{~min}$ \\
9 & Retention time & $4.59 \mathrm{~min}$ & 0.92 \\
10 & Tailing factor & 0.67 & 4640.40 \\
11 & Theoretical plates & 13619.46 & \\
\hline
\end{tabular}

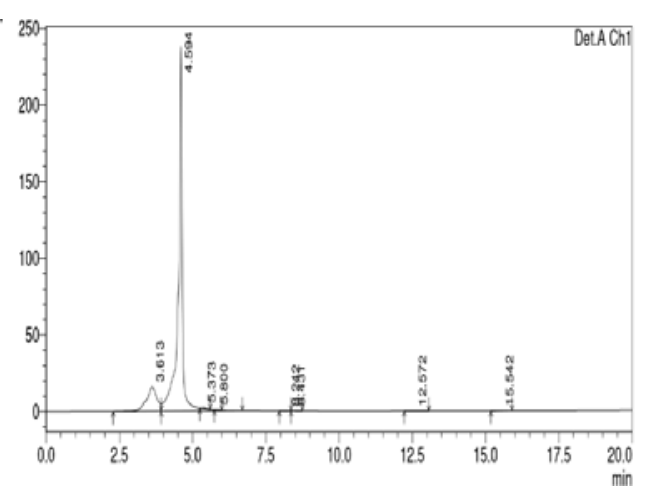

(a)

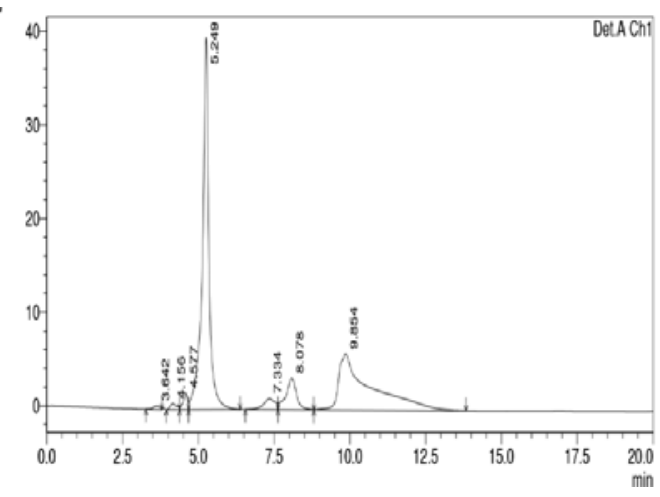

(b)

Fig. 4: (a) Typical chromatogram of ascorbic acid in EOFAE; (b) Typical chromatogram of marmelosin in AMLEAE 


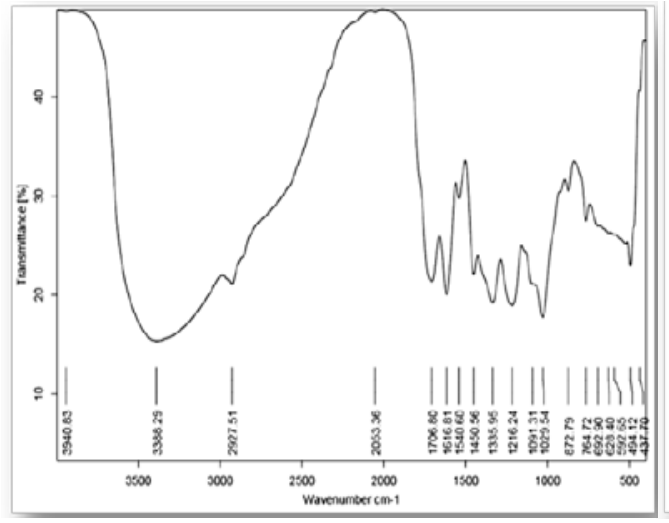

(a)

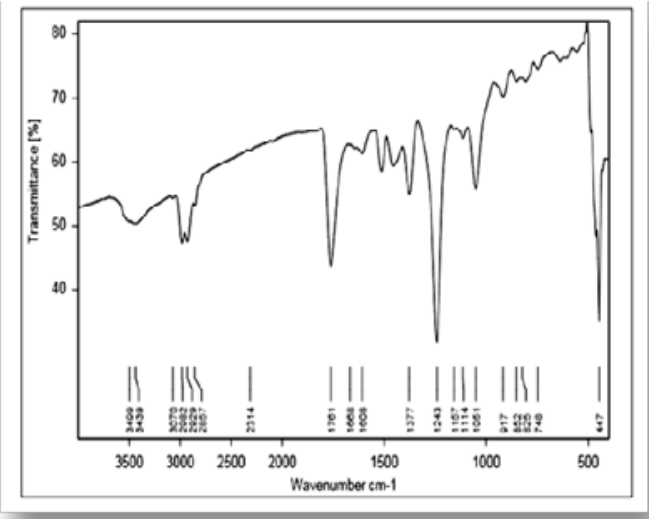

(b)

Fig. 5: FT-IR spectum for (a) EOFAE(b) FT-IR for AMLEAE

\section{Biochemical analysis}

Diabetes is associated with weight loss. Body weight get reduces in diabetic rats due to the derangement of the metabolic pathway. It causes failure to use of glucose for energy, which leads to increased utilization and decreased storage of protein responsible for the reduction of body weight. The average body weight of the experimental animals was increased treatment period as shown in table 3.

Table 3: Effect of three weeks of oral treatment of EOAM, glibenclamide and its combination in STZ-induced diabetic rats on body weight

\begin{tabular}{lll}
\hline G. No. & Groups & Body weight (gm) \\
\hline I & NC & $210.2 \pm 0.97$ \\
II & DC (50) & $164 \pm 2.73^{*}$ \\
III & EOAM (EOFAE 250+ & $250.8 \pm 3.81^{€}$ \\
& AMLEAE 250 mg/kg bw) & $242.7 \pm 6.96^{€}$ \\
IV & EOAM (EOFAE 500+ & \\
& AMLEAE 500 mg/kg bw) & $239.2 \pm 3.81^{€}$ \\
V & EOAM (EOFAE 250+ & $245 \pm 6.96^{€}$ \\
VI & AMLEAE 250 mg/kg bw)+Glib (5) & $247 \pm 9.63^{€}$ \\
VII & EOAM (EOFAE 500+ \\
\hline
\end{tabular}

$\mathrm{n}=6$, values are expressed as mean $\pm \mathrm{SEM},{ }^{*} \mathrm{p}<0.001$ as compared to $\mathrm{NWC}, \epsilon_{\mathrm{p}}<0.001$ as compared to DC

Blood Glucose Level in STZ-induced diabetic rats is significantly increased and reduced in the treatment groups shown in table 4. Diabetes mellitus is characterized by high blood glucose levels (hyperglycemia) due to the inability of the body's cells to utilize glucose properly. Increased BGL in DM produces superoxide anions which generate hydroxyl radicals via Haber-Weiss reaction. Reduction in BGL in STZ-induced diabetic rats, which means may be there is the regeneration of insulin.

Table 4: Effect of three weeks of oral treatment of EOAM, glibenclamide and its combination in STZ-induced diabetic rats on blood glucose level

\begin{tabular}{lll}
\hline G. No. & Groups & BGL (mg/dl) \\
\hline I & NC & $92.91 \pm 1.47$ \\
II & DC (50) & $365.45 \pm 5.74^{*}$ \\
III & EOAM (EOFAE 250+ & $110.71 \pm 3.76^{€}$ \\
& AMLEAE 250 mg/kg bw) & $114 \pm 4.09 €$ \\
IV & EOAM (EOFAE 500+ & \\
& AMLEAE 500 mg/kg bw) & $115.94 \pm 6.22^{€}$ \\
V & EOAM (EOFAE 250+ & \\
& AMLEAE 250 mg/kg bw)+Glib (5) & $117.83 \pm 3.55^{€}$ \\
VI & EOAM (EOFAE 500+ & $120.58 \pm 3.74^{€}$ \\
& AMLEAE 500 mg/kg bw)+Glib (5) & \\
VII & Glib (5)
\end{tabular}

$\mathrm{n}=6$, values are expressed as mean \pm SEM, $" \mathrm{p}<0.001$ as compared to NWC, $\epsilon_{\mathrm{p}}<0.001$ as compared to DC

Results of the biochemical analysis show that cholesterol and triglyceride were significantly increased and the total protein level was decreased in STZ-induced diabetes rats. Effect of EOAM on the lipid profile indicates the cholesterol (TC) and triglyceride (TG) were significantly reduced and total protein level (PROT) was increased in treatment groups as shown in table 5. These results indicate that the effective antidiabetic activity of EOAM. 
Table 5: Effect of three weeks of oral treatment of EOAM, glibenclamide and its combination in STZ-induced diabetic rats on lipid profile

\begin{tabular}{llll}
\hline G. No. & Groups & TC (mg/d) & TG (mg/dl) \\
\hline I & NC & $95.69 \pm 1.89$ & TP (gm/dl) \\
II & DC (50) & $191.11 \pm 3.28^{*}$ & $62 \pm 1.06$ \\
III & EOAM (EOFAE 250+AMLEAE 250 mg/kg bw) & $105.79 \pm 2.92^{€}$ & $165.90 \pm 1.28^{*}$ \\
IV & EOAM (EOFAE 500+AMLEAE 500 mg/kg bw) & $110.49 \pm 6.32^{€}$ & $70.88 \pm 1.29^{€}$ \\
V & EOAM (EOFAE 250+AMLEAE 250 mg/kg bw)+Glib (5) & $106.76 \pm 2.49^{€}$ & $74.91 \pm 1.00^{€}$ \\
VI & EOAM (EOFAE 500+AMLEAE 500 mg/kg bw)+Glib (5) & $109.16 \pm 3.82^{€}$ & $69.97 \pm 1.81^{€}$ \\
VII & Glib (5) & $110.1 \pm 4.31^{€}$ & $75.22 \pm 1.35^{€}$ \\
\hline
\end{tabular}

$\mathrm{n}=6$, values are expressed as mean \pm SEM, ${ }^{*} \mathrm{p}<0.001$ as compared to $\mathrm{NWC}, \mathrm{\epsilon}_{\mathrm{p}}<0.001$ as compared to DC

Diabetes is strongly co-related with oxidative stress induction. Lipid peroxidation is one of the characteristic features of diabetes mellitus and it is measured by TBARS (MDA) was used as an index of lipid peroxidation and it helps to assess the extent of tissue damage. By antioxidant assay results were found to be after three-week treatment that an increase in MDA level (Malondialdehyde) in liver of diabetic control animals. Oxidative stress in diabetes is coupled to a decrease in the antioxidant status, which can increase the deleterious effects of free radical. The SOD is the major scavenging enzymes that remove free radicals. Reduce activities of this antioxidant enzyme in liver tissue have been observed in diabetic animal and it may result in a number of deleterious effects due to an accumulation of superoxide anion and hydrogen peroxide, which in turn generate hydroxyl radicals, resulting in initiation and propagation of LPO.
SOD protects from oxygen free radicals by catalyzing the removal of superoxide radical, which damage the membrane and biological structures. SOD and GSH level significantly increase and decrease in MDA level (shown in table 5) in the treatment groups which means that the treatment groups shows a combination of both extract can reduce the potential glycation of enzymes and could exert a beneficial action against pathological alteration caused by the presence of superoxide radicals, reduces the risk of tissue damage. Glutathione (GSH) is a tripeptide, intracellular antioxidant and protects the cellular system from adverse effects of LPO. Increase in aldehyde product of LPO has probably decreased GSH content and from the present study resulting in the elevation of the GSH level, which protects the cell membrane against oxidative damage by regulating the redox status of protein in the membrane [8].

Table 5: Effect of EOAM on level of SOD, GSH and MDA after $3 \mathrm{w}$

\begin{tabular}{|c|c|c|c|c|}
\hline \multirow[t]{2}{*}{ G. No. } & \multirow[t]{2}{*}{ Groups } & \multicolumn{3}{|c|}{ In vivo antioxidant parameter } \\
\hline & & SOD (units/mg of protein) & GSH $(\mu \mathrm{M} / \mathrm{mg}$ of protein $)$ & MDA (n mol/mg of protein) \\
\hline I & $\mathrm{NC}$ & $8.74 \pm 0.27$ & $9.07 \pm 0.28$ & $7.00 \pm 0.14$ \\
\hline II & DC $(50)$ & $4.93 \pm 0.17^{*}$ & $5.07 \pm 0.17^{*}$ & $11.03 \pm 0.51^{*}$ \\
\hline III & $\begin{array}{l}\text { EOAM (EOFAE 250+ } \\
\text { AMLEAE } 250 \mathrm{mg} / \mathrm{kg} \mathrm{bw} \text { ) }\end{array}$ & $7.97 \pm 0.27^{€}$ & $8.31 \pm 0.23^{€}$ & $6.50 \pm 0.27^{€}$ \\
\hline IV & $\begin{array}{l}\text { EOAM (EOFAE } 500+ \\
\text { AMLEAE } 500 \mathrm{mg} / \mathrm{kg} \mathrm{bw})\end{array}$ & $7.23 \pm 0.26^{€}$ & $7.93 \pm 0.35^{€}$ & $6.95 \pm 0.39 €$ \\
\hline $\mathrm{V}$ & $\begin{array}{l}\text { EOAM (EOFAE } 250+ \\
\text { AMLEAE } 250 \mathrm{mg} / \mathrm{kg} \mathrm{bw})+ \text { Glib (5) }\end{array}$ & $7.40 \pm 0.46^{€}$ & $7.37 \pm 0.35^{€}$ & $6.64 \pm 0.003^{€}$ \\
\hline VI & $\begin{array}{l}\text { EOAM (EOFAE } 500+ \\
\text { AMLEAE } 500 \mathrm{mg} / \mathrm{kg} \mathrm{bw} \text { )+Glib (5) }\end{array}$ & $7.21 \pm 0.03^{€}$ & $7.62 \pm 0.49 €$ & $6.73 \pm 0.43^{€}$ \\
\hline VII & Glib (5) & $6.78 \pm 0.001^{€}$ & $7.79 \pm 0.47 €$ & $6.54 \pm 0.15^{€}$ \\
\hline
\end{tabular}

$\mathrm{n}=6$, values are expressed as mean \pm SEM, ${ }^{*} \mathrm{p}<0.001$ as compared to NWC, $€ \mathrm{p}<0.001$ as compared to DC.

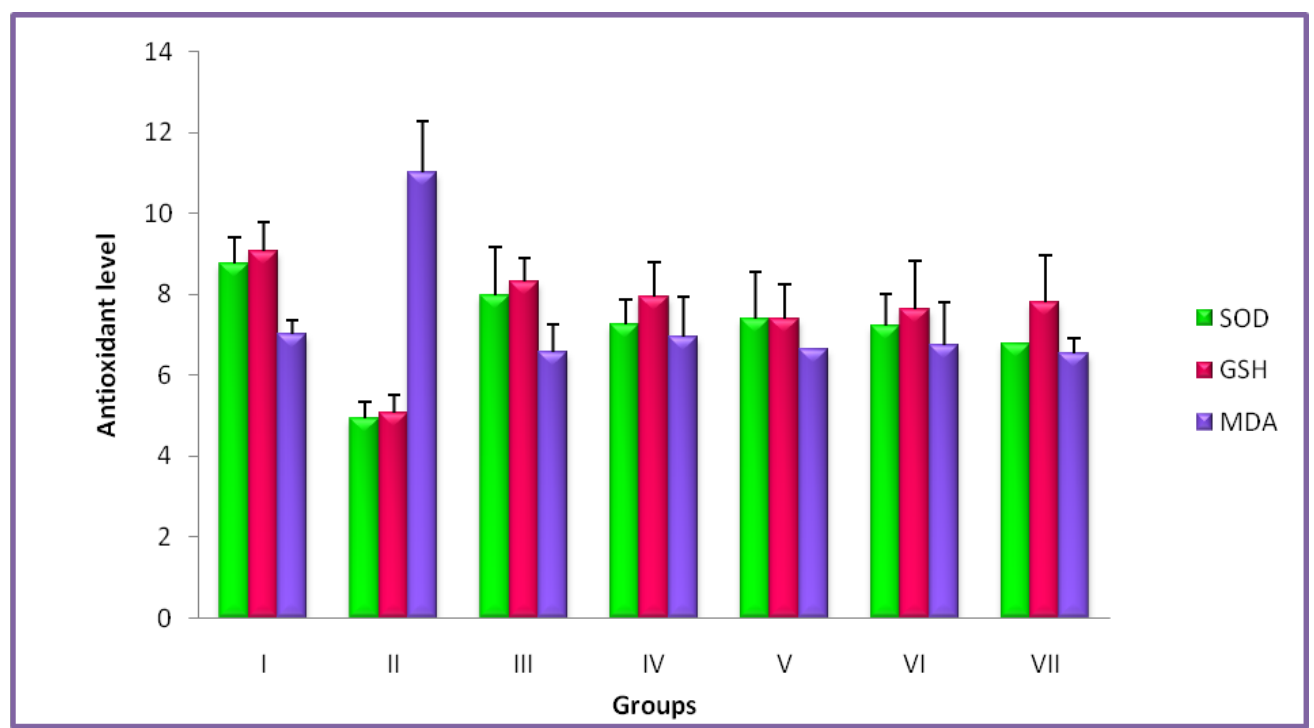

Fig. 6: Effect of three weeks of oral treatment of EOAM, glibenclamide and its combination in STZ-induced diabetic rats on antioxidant level 


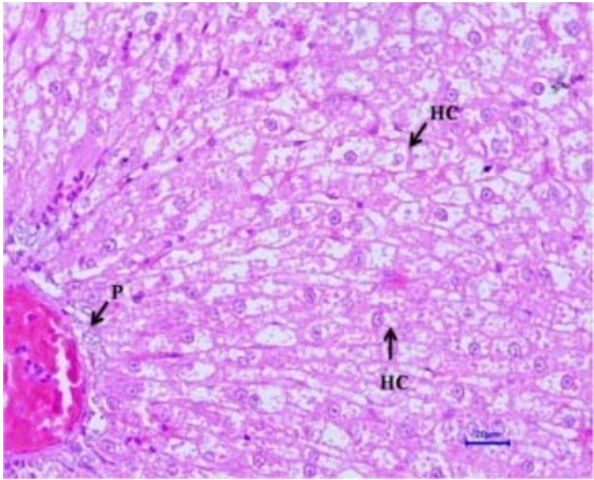

(I) NC
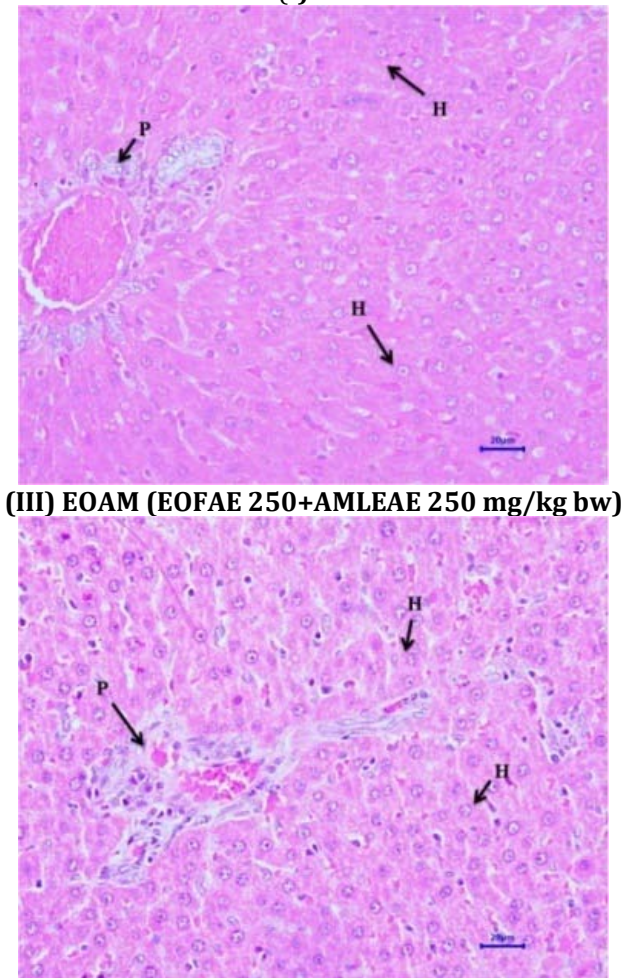

(V) EOAM (EOFAE 250+AMLEAE 250+Glib 5 mg/kg bw)

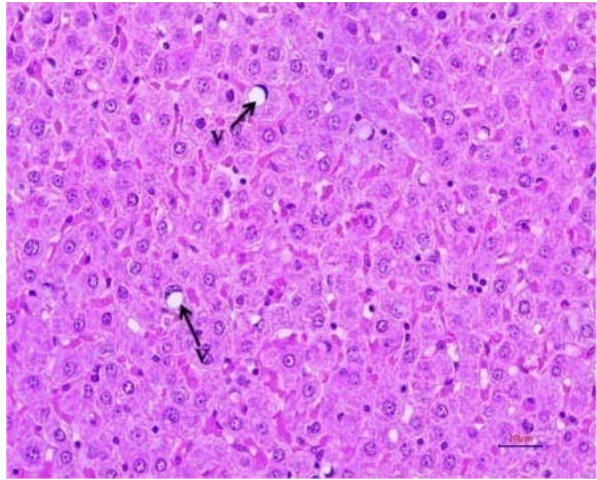

(II) DC (50)

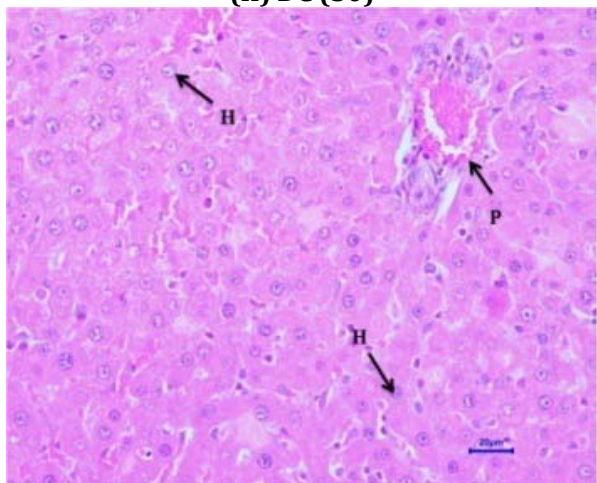

(IV) EOAM (EOFAE 500+AMLEAE $500 \mathrm{mg} / \mathrm{kgbw}$ )

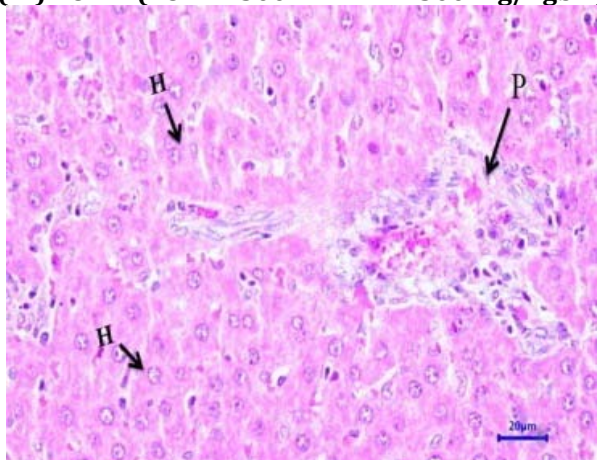

(VI) EOAM (EOFAE 500+AMLEAE500+Glib 5 mg/kg bw)

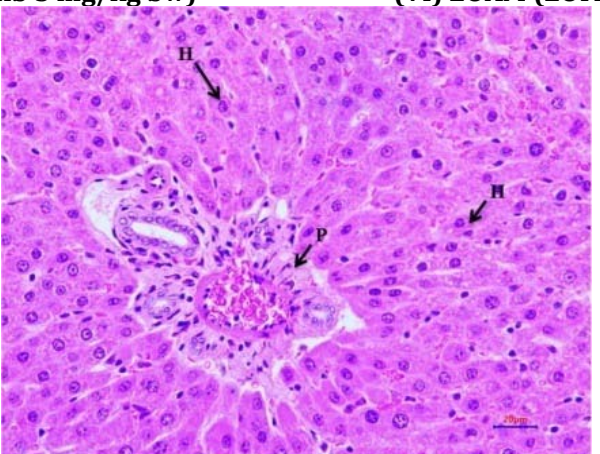

(VII) Glibenclamide $5 \mathrm{mg} / \mathrm{kg} \mathrm{bw}$

Fig. 12: Histopathological examination of experimental rat liver after $21 \mathrm{~d}$ treatment (HandE, $400 \mathrm{X}$ magnifications). Liver section of (I) Normal control, (II)Diabetic control,(III)EOAM (EOFAE 250+AMLEAE250 mg/kg bw),(IV) EOAM (EOFAE 500+AMLEAE $250 \mathrm{mg} / \mathrm{kg}$ bw, Combination of (V)EOAM (EOFAE 500+AMLEAE250+Glib $5 \mathrm{mg} / \mathrm{kg} \mathrm{bw),(VI)EOAM} \mathrm{(EOFAE} \mathrm{500+AMLEAE} \mathrm{250+Glib} 5$ mg/kg bw),(VII)Glibenclamide5 mg/kg bw.[Hepatocyte (HC), Normal Portal Triad (P), Hepatocellular Vacuolation (V), Portal Triad (P) and Hepatocyte (H)]

\section{Histopathological studies}

Histopathological examination of the experimental rat liver after 21 $\mathrm{d}$ treatment indicates that the liver section of normal control rats (NC) did not revealed any lesion of pathological significance as shown in fig. 12 (I). Liver section of diabetic control rat showed multifocal moderate hepatocellular vacuolation (microvesicular) as shown in fig. 12 (II). Liver section of diabetes-induced rats treated with low dose and high dose did not revealed any lesion of pathological significance as shown in fig. 12 (III) and (IV) Combination of low dose and high dose with glibenclamide also did not revealed any lesion of pathological significance as shown in fig. 
12 (V) and (VI). Standard drug did not revealed any lesion of pathological significance as shown in fig. 12 (VII). Histopathology of the liver of STZ induced diabetic animals showed that there were hepatic changes, mild portal inflammation and hepatocellular vacuolation. After treatment of the animals by EOAM and glibenclamide, there was normal histology and reduced severity of the histopathological changes caused by STZ. The present study shows that the EOAM treated group III have significant antioxidant and antidiabetic activity as compare to diabetic control STZ induced animals. Equiproportion combination of both extracts shows significantly decreased in oxidative stress as evidenced by improved activities of antioxidant enzymes like superoxide dismutase, reduced glutathione. From the histological studies the liver section of group V and VI may have some interactions and liver section of diabetesinduced rats groups III, IV treated with EOAM and VII treated with well known sulfonylurea drugs like glibenclamide did not revealed any lesion of pathological significance, where the group III shows good significant effect $(\mathrm{p}<0.001)$ as compare to STZ-induced diabetic rats.

Conclusion: From the phytochemical investigation, hydrolyzable phytoconstituents like ascorbic acid, tannins like emblicanin A and B present in the aqueous extract which helps to increase the antioxidant activity and marmelosin present in the Aegle marmelos ethyl acetate extract which have potent antidiabetic activity. In vitro, antioxidant assay shows that both extracts have significant antioxidant activity. In vivo study reveals that the group III treated with EOAM (containing EOFAE 250+AMLEAE $250 \mathrm{mg} / \mathrm{kg}$ body weight) shows more significant in the reduction of blood glucose level, cholesterol, triglycerides, MDA level and concomitant increase in the serum protein level, SOD and GSH activities as compared to STZ-induced diabetic control rats. It can be concluded that equiproportion combination of both extracts exhibits synergistic effect, safe and has significant antioxidant and antidiabetic activity.

\section{AUTHORS CONTRIBUTIONS}

All the authors have contributed equally

\section{CONFLICT OF INTERESTS}

Declared none

\section{REFERENCES}

1. www.who.int/news-room/fact-

sheets/details/diabetes15November2017. [Last accessed on 25 Dec 2017].

2. https://auroushealthcare.wordpress.com/2018/05/11/icmrissues-new-guidelines-for-type-2-diabetes-management-aspatient-numbers-touch-72-9-million. [Last accessed on 25 Aug 2018].

3. Anjana RM, Deepa M, Pradeepa R, Mahanta J, Narain K, Das HK, et al. Prevalence of diabetes and prediabetes in 15 states of India: results from the ICMR-INDIAB population-based crosssectional study. Lancet Diabetes Endocrinol 2017;5:585-96.

4. Yokota N, Miyakoshi T, Sato Y, Nakasone Y, Yamashita K, Imai T, et al. Predictive models for the conversion of prediabetes to diabetes. J Diabetes Its Complications 2017;31:1266-71.

5. http://www.who.int/mediacentre/factsheets/fs138/en. [Last accessed on 08 April 2018].

6. www.cdc.gov/diabetes/pdfs/data/statistics/national-diabetesstatistics-report. [Last accessed on 06 Aug 2017]

7. https://www.diabetes.co.uk/features/diabetes-medicationside-effects.html. [Last accessed on 06 May 2018]

8. Nain P, Saini V, Sharma S, Nain J. Antidiabetic and antioxidant potential of Emblica officinalis gaerth leaves extract in streptozotocin-induced type-2 diabetes mellitus (T2DM) rats. J Ethnopharmacol 2012;142:65-71.

9. Narendhirakannan RT, Subramanian S. Biochemical evaluation of the protective effect of Aegle marmelos (L.), corr. leaf extract on tissue antioxidant defence system and histological changes of pancreatic $\beta$-cells in streptozotocin-induced diabetic rats. Drug Chem Toxicol 2010;33:120-30.

10. Scartezzini P, Antognoni F, Raggi MA, Poli F, Sabbioni C. Vitamin $C$ content and antioxidant activity of the fruit and of the Ayurvedic preparation of Emblica officinalis Gaertn. J Ethnopharmacol 2006;104:113-8.
11. Ansari A, Shahriar MS, Hassan MM, Das SR, Rokeya B, Haque $\mathrm{MA}$, et al. Emblica officinalis improves glycemic status and oxidative stress in STZ induced type 2 diabetic model rats. Asian Pac J Trop Med 2014;7:21-5.

12. Badoni Himani, Sharma Promila, Waheed Syed Mohsin, Singh Saumy. Phytochemical analyses and evaluation of antioxidant, antibacterial and toxic properties of Embilica officinalis and Terminalia bellirica fruit extract. Asian J Pharm Clin Res 2016;6:96-102.

13. Asaduzzaman. Phytochemicals, nutritional constituent, antibacterial and Hypogycemic activity of A. Marmelos lin. leaf extract in alloxan-induced diabetic rat. J Nutr Food Sci 2016;4:1-7.

14. Sankeshi V, Kumar PA, Naik RR, Sridhar G, Kumar MP, Gopal $\mathrm{VH}$, et al. Inhibition of aldose reductase by Aegle marmelos and its protective role in diabetic cataract. J Ethnopharmacol 2013;149:215-21.

15. Karmase A, Jagtap S, Bhutani KK. Antiadipogenic activity of Aegle marmelos correa. Phytomedicine 2013;20:1267-71.

16. Kesari AN, Gupta RK, Singh SK, Diwakar S, Watal G. Hypoglycemic and antihyperglycemic activity of Aegle marmelos seed extract in normal and diabetic rats. J Ethnopharmacol 2006;107:374-9.

17. Kumar GS, Nayaka H, Dharmesh SM, Salimath PV. Free and bound phenolic antioxidants in amla (Emblica officinalis) and turmeric (Curcuma longa). J Food Composition Anal 2006;19:446-52.

18. Ladva BJ, Mahida VM, Kantaria UD, Gokani RH. Marker based standardization of polyherbal formulation (SJT-DI-02) by high performance thin layer chromatography method. J Pharm Bioallied Sci 2014;6:213.

19. Parveen R, Shamsi TN, Singh G, Athar T, Fatima S. Phytochemical analysis and in vitro biochemical characterization of aqueous and methanolic extract of triphala, a conventional herbal remedy. Biotechnol Rep 2018;17:126-36.

20. Panaskar SN, Joglekar MM, Taklikar SS, Haldavnekar VS, Arvindekar AU. Aegle marmelos correa leaf extract prevents secondary complications in streptozotociinduced diabetic rats and demonstration of limonene as a potent antiglycating agent. J Pharm Pharmacol 2013;65:884-94.

21. Krishnaiah D, Sarbatly R, Nithyanandam R. A review of the antioxidant potential of medicinal plant species. Food Bioprod Process 2011;89:217-33.

22. Karmase A, Prasanna K, Rasabattula S, Bhutani KK. Quantification and comparison of extraction methods for alkaloids in Aegle marmelos leaves by HPLC. Nat Prod Commun 2014;9:981-3.

23. Sawant L, Prabhakar B, Pandita N. Quantitative HPLC analysis of ascorbic acid and gallic acid in Phyllanthus emblica. J Anal Bio Anal Techniques 2010;1:111.

24. Panicker CY, Varghese HT, Philip D. FT-IR, FT-Raman and SERS spectra of Vitamin C. Spectrochim Acta Part A 2006;65:802-4.

25. Pynam H, Dharmesh SM. Antioxidant and anti-inflammatory properties of marmelosin from Bael (Aegle marmelos L.); inhibition of TNF- $\alpha$ mediated inflammatory/tumor markers. Biomed Pharmacother 2018;106:98-108.

26. Usharani P, Fatima N, Muralidhar N. Effects of Phyllanthus emblica extract on endothelial dysfunction and biomarkers of oxidative stress in patients with type 2 diabetes mellitus: a randomized, double-blind, controlled study. Diabetes Metab Syndr Obes: Targets Ther 2013;6:275.

27. Sabu MC, Kuttan R. Antidiabetic activity of Aegle marmelos and its relationship with its antioxidant properties. Indian J Physiol Pharmacol 2004;48:81-8.

28. Allain CC, Poon LS, Chan CS, Richmond WF, Fu PC. Enzymatic determination of total serum cholesterol. Clin Chem 1974;20:470-5.

29. Bucolo G, David H. Quantitative determination of serum triglycerides by the use of enzymes. Clin Chem 1973;19:476-82.

30. Gornall AC, Bardawal CJ, David MJ. Determination of serum proteins by means of the biuret reaction. Bio Chem 1949;177:751-66.

31. Tietz NW, Pruden EL, Siggaard-Andersen O. Electrolytes, blood gases, and acid-base balance. Tietz Fundamental of Clinical Chemistry; 1986. 
32. Ellman GL. Tissue sulphydryl groups. Arch Biochem Biophys 1959;82:70-7.

33. Okhawa H, Ohishi N, Yagi K. Assay for lipid peroxides in animal tissues by thiobarbituric reaction. Anal Biochem 1979;95:351-8.

34. Lowry $\mathrm{OH}$, Rosenbourgh NJ, Farr AL, Randall R. Protein determination using folin-ciocalteu reagent. J Biol Chem 1951;193:265-9.

35. Panda S, Kar A. Synergistic interactions of Aegle marmelos leaf, Emblica officinalis fruit and Ocimum sanctum leaf extracts in the regulation of hyperthyroidism and/or hyperglycaemia. Orient Pharm Exp Med 2004;4:37-43.

36. Bihani GV, Rojatkar SR, Bodhankar SL. Investigation of in vivo analgesic and anti-inflammatory activity in rodents and in vitro antioxidant activity of extracts of whole plant of Cyathocline purpurea. Int J Pharm Pharm Sci 2014;6:492-8.

37. Sruthi T, Satyavati D, Upendar K, Kumar CP. Antidiabetic activity and anti-oxidant activity of niddwin, a polyherbal formulation in alloxan induced diabetic rats. Int J Pharm Pharm Sci 2014;6:273-7. 